\title{
STRATEGI IMPLIKATUR PERCAKAPAN ANAK USIA 3-6 TAHUN
}

\author{
Chrissanty Hiariej \\ Universitas Pattimura \\ e-mail: chrissantyhiariej@yahoo.com
}

\begin{abstract}
Abstrak: Implikatur percakapan merupakan bagian dari pertuturan yang digunakan untuk menyampaikan maksud penutur. Umumnya implikatur sering ditemukan dalam percakapan orang dewasa. Namun, setelah diteliti, implikatur juga dapat muncul dalam percakapan anak-anak. Anak-anak khususnya usia 3-6 tahun sudah memahami dan mengekspresikan perasaan, keinginan dan harapan mereka yang diperoleh dari keluarga, lingkungan, dan pendidikan. Penelitian ini bertujuan mendeskripsikan strategi implikatur percakapan bahasa Indonesia anak usia 3-6 tahun.

Penelitian ini bersifat deskriptif kualitatif. Teknik yang dipakai dalam pangumpulan data implikatur percakapan anak usia 3-6 tahun di Ambon adalah teknik observasi, teknik pemancingan, teknik rekaman, teknik catatan lapangan. Penganalisisan data penelitian ini menggunakan metode padan alat penentu pragmatis. Prosedur penganalisisan data dilakukan melalui tiga alur kegiatan yang terjadi secara bersamaan untuk menjawab semua rumusan masalah penelitian ini yaitu reduksi data, penyajian data dan verifikasi atau penyimpulan. Hasil penelitian menunjukkan bahwa implikatur percakapan anak usia 3-6 tahun muncul ketika anak bersama banyak orang, seperti berada dengan kumpulan teman-teman yang sebaya, dan orang dewasa di sekitarnya. Hasil penelitian menunjukkan bahwa strategi implikatur percakapan anak usia 3-6 tahun terdiri atas delapan strategi, yaitu strategi pemberian petunjuk, pemberian petunjuk asosiasi, praanggapan, pemahaman, pernyataan lebih, ironi, penggunaan metafora, dan pertanyaan retoris.
\end{abstract}

Kata Kunci: Implikatur percakapan, strategi, dan anak usia 3-6 tahun. 


\title{
THE IMPLICATURE CONVERSATIONAL STRATEGY OF 3-6 YEARS OLD CHILDREN
}

\author{
Chrissanty Hiariej \\ Universitas Pattimura \\ e-mail: chrissantyhiariej@yahoo.com
}

\begin{abstract}
Conversation Implication is part of conversation that is used to convey the speaker's mean. Commonly it is often found in adult conversation. However, after being researched, implication also can be found in children conversation. Children, notably Children Age 3-6 Years has already understood and expressed their feelings, wishes, and hopes which are gained through their family, environment, and education. The objectives of the research are to describe the strategy of The Implicature Indonesian Language Conversation of Children Age 3-6 Years.
\end{abstract}

This research is a descriptive qualitative research. The technique that is used to gather the conversation implication data of Children Age 3-6 Years in Ambon is observation technique, debouching technique, recording technique, field note technique. In analyzing data, this research used pragmatic determining tool match method. The data analysis procedures have been done through three simultaneously activities to answer the entire research problems which are data reduction, data presentation, and verification or conclusion. The research result shows that Children Age 3-6 Years conversation implication will appear when the children are surrounded by many people, for example friends and adult. Based on the research focus of research result shows that based on researcher's findings, Children Age 3-6 Years conversation implication strategy, there are eight strategies. They are giving direction strategy, giving association strategy, presuppose, understate, overstate, be ironic, metaphor using, and use rhetorical question.

Keywords: conversation implication, strategy, and children Age 3-6 Years 


\section{A. PENDAHULUAN}

Bahasa digunakan sebagai sistem komunikasi masyarakat. Sebagai sistem komunikasi, bahasa dapat memengaruhi tingkah laku sosial. Hal itu berarti bahasa dianggap sebagai kesatuan dari struktur masyarakat. Cara seseorang menggunakan sistem-sistem dalam bahasa bergantung pada penutur dan hal yang disampaikannya. Bahasa yang digunakan dalam interaksi perlu disesuaikan dengan aspek penunjang bahasa, yaitu pengguna bahasa dan jenis bahasa yang digunakan.

Fungsi bahasa dalam komunikasi, kalau dilihat berdasarkan tanggapan atau respons mitra tutur, terdiri atas dua kategori yaitu fungsi transaksional dan fungsi interaksional. Bahasa berfungsi transaksional apabila yang dipentingkan dalam penggunaannya adalah isinya. Dengan fungsi transaksional, bahasa dapat digunakan sebagai penyalur informasi. Fungsi tersebut, menurut Brown dan Yule (1996:1-2) dinyatakan sebagai fungsi transaksional bahasa yang utama (Primarily transactional language). Berbeda dengan fungsi transaksional, fungsi interaksional digunakan ketika yang dipentingkan adalah hubungan timbal balik antara penyapa dan pesapa. Fungsi bahasa interaksional dinyatakan dalam percakapan sehari-hari.

Dalam percakapan sehari-hari, setiap ucapan yang disampaikan oleh penutur selalu memunyai makna dan maksud yang diwujudkan dalam bentuk ujaran. Ujaran yang disampaikan mencerminkan masyarakat tutur. Dengan demikian, ujaran pun berkaitan dengan norma dan nilai sosial budaya masyarakat. Hal itu dibuktikan dengan konsep bahwa kelancaran berkomunikasi dalam pertuturan perlu ditunjang oleh kesamaan latar belakang pengetahuan tentang sesuatu yang dipertuturkan. Di antara penutur dan mitra tutur terdapat semacam kontrak percakapan tidak tertulis, bahwa apa yang sedang dipertuturkan saling dimengerti (Rahardi,2005:43). Kalau dalam tuturan terdapat makna serta maksud tertentu dari sesuatu yang dikatakan, ucapan tersebut memunyai implikatur.

Agar proses komunikasi dapat berjalan lancar, Grice menjelaskan bahwa dalam implikatur percakapan, prinsip kerja sama turut berperan sehingga maksud penutur sampai pada interpretasi yang dimaksudkan terhadap mitra tutur. Bagi Grice, kerja sama merupakan prinsip yang mengatur rasionalitas pada umumnya dan rasionalitas percakapan pada khususnya. Grice (dalam Cummings, 2007:14) mengemukakan definisinya tentang prinsip kerjasamanya dalam bentuk perintah yang diarahkan pada penutur, bahwa kontribusi percakapan harus sesuai dengan yang diperlukan pada tahap terjadinya kontribusi itu. Prinsip tersebut didasarkan pada tujuan atau arah yang diterima dalam percakapan yang dilakukan. Dengan kata lain, prinsip kerja sama tidak menyatakan secara tepat apa yang 'diminta' dari suatu kontribusi percakapan.

Dalam komunikasi, implikatur percakapan memiliki makna yang bervariasi. Pemahaman terhadap hal-hal "yang dimaksudkan" bergantung pada konteks percakapan (Mulyana, 2005:13). Konteks ialah situasi atau latar terjadinya suatu komunikasi. Konteks dianggap sebagai sebab dan alasan terjadinya suatu percakapan atau dialog. Segala sesuatu yang berhubungan dengan tuturan, baik itu berkaitan dengan arti, maksud maupun informasinya tergantung pada konteks yang melatarbelakangi peristiwa tuturan itu.

Percakapan sebaiknya bersifat relevan dengan konteks, jelas, dan mudah dipahami. Melalui percakapan, implikatur dimanfaatkan untuk menyampaikan maksud. Implikatur digunakan untuk menjembatani percakapan. Umumnya implikatur sering ditemukan dalam percakapan orang dewasa. Berdasarkan observasi, implikatur juga dapat muncul 
dalam percakapan anak-anak. Pada penelitian-penelitian terdahulu sudah banyak diteliti implikatur percakapan orang dewasa, sedangkan implikatur percakapan anak belum banyak yang diteliti. Dengan demikian, peneliti akan meneliti implikatur percakapan anak, dengan melihat aspek lain dalam implikatur percakapan. Konsep implikatur percakapan anak yang diteliti dapat dijadikan sebagai bandingan pada konsep implikatur orang dewasa umumnya.

Fokus penelitian ini adalah anak usia 3-6 tahun. Fokus ini dipilih karena anak pada usia 3-6 tahun sudah memiliki pengalaman yang cukup dalam komunikasi pada tahapan pemerolehan bahasa pertama yang dipengaruhi oleh keluarga maupun lingkungan. Sifat yang biasanya terjadi pada anak-anak adalah menirukan dan mendapatkan rangsangan dari orang sekitar, seperti apa yang dilihat, didengar, dan yang pernah dialami.

King (2013:47 - 53) merinci perkembangan bahasa anak pada usia 3 - 4 tahun ratarata panjangnya ucapan mencapai 3-4 morfem dalam sebuah kalimat, penggunaan kalimat tanya "ya" dan "tidak", pertanyaan "apa," "siapa", "mengapa" dan "kapan", penggunaan kalimat negatif dan kalimat perintah, serta kesadaran yang meningkat terhadap pragmatis. Hal itu yang menjadi dasar bahwa anak usia 3-6 tahun sudah mampu dalam pragmatik. Secara tidak langsung, kemampuan berimplikatur anak juga sudah meningkat. Dengan kata lain, anak usia 3-6 tahun sudah ada pada tahapan memahami maksud tuturan dan dapat berinteraksi secara pragmatis.

Tidak hanya itu, anak usia 3-6 tahun sudah memproduksi kalimat yang cukup kompleks serta anak juga sudah memiliki perluasan kosakata yang pesat dan memahami maksud dari yang diucapkan mitra tuturnya. Pada umur tiga sampai lima tahun anak menggunakan bahasa sebagai alat untuk memeroleh informasi. Anak juga sudah mampu menangkap makna dan maksud dibalik sebuah tuturan yang diperoleh dari lingkungan sekitarnya. Hal tersebut ditandai dengan proses pemahaman yang terjadi secara alami. Selain itu, anak-anak khususnya usia 3-6 tahun sudah memahami dan mengekspresikan perasaan, keinginan dan harapan mereka yang diperoleh dari keluarga, lingkungan, dan pendidikan. Anak akan berusaha menyampaikan maksud dan tujuannya dalam bentuk implikatur sebagai respons dari apa yang disampaikan oleh mitra tuturnya, bahkan apa yang menjadi kebiasaan-kebiasaan anak.

Dalam kaitannya dengan interaksi percakapan anak usia 3-6 tahun, subjek penelitian ini terdiri atas enam orang anak. Anak-anak ini dipilih atas dasar kebiasaan menggunakan implikatur percakapan setiap hari, ketika berinteraksi dengan orang-orang sekitar. Secara umum, alasan lain pemilihan subjek ini adalah berdasarkan pemikiran bahwa implikatur selalu terkait dengan konteks, sosial, pendidikan dan budaya.

Budaya acapkali dihubungkan dengan kebiasaan dan maksud dari suatu tuturan. Setiap daerah tentu memiliki tingkat kebiasaan dan gaya berbahasa yang berbeda sesuai budaya daerah tersebut. Misalnya, Untuk budaya Indonesia bagian barat, dalam berkomunikasi, basa-basi dianggap penting dan santun untuk menangkap suatu maksud. Berbeda dengan budaya timur khususnya Ambon, berbicara secara langsung dianggap lebih santun dibandingkan harus berbasa-basi dalam komunikasi. Namun, ujaran langsung itu menggunakan bahasa yang berbeda atau bernilai rasa lebih santun. Dengan demikian, kemungkinan besar implikatur digunakan sebagai proses menjembatani percakapan. Hal itu sekaligus menjadi alasan peneliti memilih objek penelitian di Desa Halong Kecamatan Baguala Ambon, karena disesuaikan dengan tempat subjek tinggal 
dan dihubungkan dengan budaya Indonesia Timur pada Kota Ambon. Dengan demikian, kesantunan berhubungan dengan bahasa dan budaya. Sama halnya budaya selalu diwariskan pada anak-anak, implikatur percakapan anak juga diperoleh dari proses budaya melalui kebiasaan mendengarkan percakapan orang dewasa.

\section{B. METODE PENELITIAN}

Penelitian ini bersifat deskriptif kualitatif karena bertujuan mendeskripsikan secara terperinci serta mendalam implikatur percakapan bahasa Indonesia anak usia 3-6 tahun dengan berfokus pada subjek yang telah dipilih peneliti. Oleh karena itu, peneliti menentukan jumlah subjek penelitian adalah enam orang, namun pada satu tempat atau satu objek penelitian. Penelitian ini juga menggunakan cara induktif karena tidak bermaksud menguji hipotesis.

Teknik yang dipakai dalam pangumpulan data implikatur percakapan anak usia 36 tahun di Ambon selama bulan april sampai bulan juni adalah teknik observasi, teknik pemancingan, teknik rekaman, teknik catatan lapangan. Penganalisisan data penelitian ini menggunakan metode padan alat penentu pragmatis. Metode padan yang digunakan adalah teknik dasar hubung banding yang bersifat ekstralingual karena teknik ini dianggap cocok untuk mengaji atau menentukan identitas satuan lingual yang berada di luar bahasa, yaitu secara pragmatik. Selain alasan pemakaian teknik penganalisisan tersebut, analisis yang digunakan dalam penelitian implikatur percakapan anak usia 36 tahun merupakan analisis "membedah" data dari konteksnya (aspek lain seperti lingkungan fisik atau sosial berkaitan dengan ujaran serta maksud tuturan). Pada tahap penganalisisan data kegiatan pokok yang dilakukan adalah mengklasifikasi data untuk mengorganisasikan data agar siap disajikan pada tahap penyajian data. Pada tahap ini, peneliti melakukan pemilahan, penyederhanaan, pengkodean, dan pembuangan data yang tidak diperlukan. Prosedur penganalisisan data dilakukan melalui tiga alur kegiatan yang terjadi secara bersamaan untuk menjawab semua rumusan masalah penelitian ini yaitu reduksi data, penyajian data dan verifikasi atau penyimpulan.

\section{PEMBAHASAN}

Leech (2011:45) dengan mengikuti pendapat Grice menyatakan bahwa implikatur harus mampu dijelaskan. Pemikiran Leech mengarah pada kajian pragmatik mengaji pada perilaku yang dimotivasi oleh tujuan-tujuan percakapan. Hal itu ditegaskan dengan pendapat bahwa apa yang dimaksud oleh si penutur dengan tuturannya tidak pernah dapat kita ketahui dengan pasti sekali. Hal ini disebabkan oleh faktor-faktor seperti kondisikondisi yang diamati, tuturan, dan konteks. Dengan demikian, dengan faktor-faktor ini mitra tutur bertugas untuk menginterpretasi yang paling mungkin. Dalam tahap penafsiran, Leech menafsirkan makna melalui tiga tahap penafsiran.

a. Menolak interpretasi pengamatan pertama karena tidak taat asas dengan prinsip kerja sama.

b. Mencari interpretasi baru yang taat asas dengan prinsip kerja sama.

c. Menemukan interpretasi baru dan memastikan bahwa interpretasiini taat asas dengan prinsip kerja sama. 
Berdasarkan tiga tahap ini, jika dihubungkan dengan implikatur percakapan, interpretasi yang baru merupakan bagian dari implikatur percakapan. Implikatur percakapan dibutuhkan mitra tutur untuk memahami maksud serta taat asas dalam pertuturan. Untuk taat asas, ada salah satu asas yang harus diabaikan. Tahapan-tahapan yang telah disebutkan itu secara logika dapat dijadikan sebagai strategi untuk memahami maksud implikatur percakapan.

Tidak berbeda dengan Grice, Leech juga sependapat dengan Searle (Leech, 2011:49) yang menegaskan bahwa interpretasi khususnya penafsiran ilokusi-ilokusi yang tidak langsung merupakan tindak ilokusi yang dilakukan dengan tidak langsung melalui suatu tindak ilokusi lain. Ilokusi-ilokusi yang dimaksudkan adalah ilokusi yang membutuhkan sebuah penjelasan berpolakan implikatur percakapan. Hal itu sejalan dengan Grice yang menjelaskan bahwa kalimat-kalimat tidak langsung, maknanya lebih banyak daripada yang diucapkan oleh penutur. Dengan demikian, kaidah yang sama juga merupakan bagian dari pemahaman Grice.

Strategi berimplikatur Leech (2011:55-56) dikenal dengan strategi pemecahan masalah oleh penutur dapat dilihat sebagai sebuah bentuk analisis cara-tujuan (meanend). Menurut Brown dan Levinson (1987:213-227) dalam penyampaian implikatur percakapan, terdapat 10 strategi berimplikatur percakapan, yaitu penggunaan petunjuk, penggunaan petunjuk asosiasi, pengandaian, pemahaman, pernyataan lebih, tautologi, penggunaan kontradiksi, ironi, penggunaan metafora, dan pertanyaan retoris. Berikut ini disajikan data-data strategi berimplikatur yang digunakan berdasarkan penelitian implikatur percakapan bahasa Indonesia anak usia 3-6 tahun.

\section{Pemberian Petunjuk}

Strategi memberikan petunjuk diasumsikan jika tuturan $\mathrm{N}$ yang mengatakan sesuatu tidak terkait secara eksplisit, berarti $\mathrm{N}$ mengajak $\mathrm{T}$ untuk mencari penafsiran yang mungkin relevansi. Mekanisme dasar ini merupakan pelanggaran terhadap maksim relevansi. Oleh karena itu, petunjuk diperlukan untuk 'meningkatkan pemikiran dari suatu tindakan yang dinyatakan, misalnya motif atau alasan untuk melakukan sesuatu. Setiap langkah-langkah dalam penalaran yang bersifat praktis mengarah pada sesuatu yang ingin dilakukan. Cara untuk memahami dapat digunakan sebagai petunjuk yang melibatkan respon dari pendengar.

(1) MU: Alya tidur

CP : Mama Ucan kipas! Ade tidak bisa nafas.

MU: (mematikan kipas)

Konteks: Percakapan terjadi ketika Alya dan mama Susan sedang tidur siang di kamar menggunakan kipas angin.

Percakapan data (1) pengalaman dan kebiasaan merupakan salah satu keunggulan yang digunakan untuk memahami maksud dari tuturan. Dengan pengalaman yang dialami MU Tuturan CP "Mama Ucan kipas" dapat dipahami sebagai perintah untuk mematikan 
kipas angin. Pada data (1) CP menggunakan strategi implikatur percakapan penggunaan petunjuk untuk menyampaikan maksud dari tuturannya. Dengan respons MU sebagai mitra tutur CP Nampak bahwa komunikasi dan strategi penggunaan petunjuk pada tuturan $\mathrm{CP}$ berjalan dengan baik.

\section{Pemberian Petunjuk Asosiasi}

Strategi petunjuk asosiasi terkait dengan implikatur pelanggaran relevansi yang diberikan dengan menyebutkan sesuatu yang berhubungan dengan tindakan yang diperlukan dari $\mathrm{T}$, baik berdasarkan pengalaman atau pengetahuan mereka yang dihubungankan dari pengalaman interaktional. Brown dan Levinson (1989:215) menyatakan bahwa pemberian petunjuk asosiasi dapat dipilah dalam dua kategori, yaitu strategi pemberian petunjuk asosiasi yang terkait dengan pengetahuan bersama antara $\mathrm{N}$ dan $\mathrm{T}$, dan strategi penggunaan petunjuk asosiasi terlepas dari pengetahuan bersama antara $\mathrm{N}$ dan $\mathrm{T}$.

(2) $\mathrm{CH}(1)$ : Eman tinggal di mana?

HK(1): Di rumah saya

$\mathrm{CH}(2)$ : Rumah di mana?

HK(2): Rumah mama saya. Papa sudah pesan rumah baru. Dekat saja

Konteks: Ketika CH berkunjung ke rumah HK, tetapi tidak tahu HK tinggal di rumah kakeknya atau bersama orang tuanya.

Berdasarkan pengalaman interaksional, data (2) jawaban HK(2) "Di rumah mama saya. Papa sudah pesan rumah. Dekat saja" mengimplikasikan bahwa HK mengarahkan pada rumah yang sedang HK tinggal sekarang. Tuturan "Dekat saja" memberikan kontribusi yang berlebihan, tetapi mengantung maksud ajakan pada $\mathrm{CH}$ untuk berkunjung ke rumah baru HK. Pernyataan HK "Dekat saja" berlawanan dengan maksim relevansi. Namun, terkait dengan pengetahuan bersama antara $\mathrm{CH}$ dan $\mathrm{HK}$. Dengan demikian, strategi yang nampak pada data (2) adalah strategi petunjuk asosiasi.

Data yang disajikan tidak terlepas dari konsep strategi petunjuk asosiasi menurut Brown dan Levinson (1987:215-2016) yang menyatakan bahwa strategi petunjuk asosiasi terkait dengan implikatur pelanggaran relevansi. Strategi petunjuk asosiasi berhubungan dengan tindakan yang diperlukan dari mitra tutur. Tindakan yang diperlukan biasanya didasarkan pada pengalaman atau pengetahuan bersama yang dihubungkan dari pengalaman interaksional.

\section{Praanggapan}

Strategi praanggapan digunakan sebagai petunjuk untuk maksud penutur terkait dengan maksim relevansi. Ucapan dapat sepenuhnya relevan dalam konteks, namun melanggar maksim relevansi hanya pada tingkat praanggapan tersebut. Penggunaan strategi ini untuk mencari yang relevan dari praanggapan sebelum peristiwa pertuturan. 
Jika hal ini hanya terkait dengan asumsi itu dan $\mathrm{T}$ yang bertugas untuk memahami. Strategi praanggapan (presuppose), dapat diamati pada data berikut.

(3) HK: Noel pinjam (melihat tangan Noel)

NS : Kalau pinjam kaset di Noel bisa

Konteks: Percakapan terjadi ketika NS dan HK sedang bercerita tentang film Naruto. NS memegang kaset film. HK terus melihat kaset yang dipegang NS.

Berdasarkan percakapan pada data (3) strategi yang digunakan HK dalam berimplikatur percakapan adalah strategi Praanggapan. Data (3) digolongkan sebagai strategi praanggapan karena cara yang digunakan untuk menyampaikan maksud tuturan memerlukan anggapan sebelum peristiwa pertuturan. Asumsi ini dipertegas dengan alasan bahwa HK sebelumnya telah memunyai referensi berupa anggapan sebelumnya yang terkait dengan kaset milik NS. Jika dihubungkan dengan konsep prinsip kerja sama, tuturan HK dan NS melangkar maksim relevansi. Melalui pengalaman dan percakapan sebelumnnya yang terungkap melalui konteks percakapan, NS sudah memunyai referen yang terkait dengan sikap dan tuturan HK. Hal yang sama juga dipahami HK, sehingga HK menuturkan "Noel pinjam" sebagai cara meminjam kaset dari NS melalui tuturan berimplikatur percakapan.

\section{Pemahaman}

Strategi pemahaman bertujuan untuk menginterpretasikan tujuan ilokusi $\mathrm{N}$ dengan cara memahami bahwa $\mathrm{N}$ melakukan pelanggaran maksim kuantitas. Dalam hal ini terdapat dua strategi, yaitu mempertimbangkan bagaimana penerima bisa diajak untuk membuat kesimpulan dengan pelanggaran $\mathrm{N}$ dari maksim kuantitas. Hal itu berarti implikatur percakapan melanggar maksim kuantitas ('Katakanlah sesuatu yang tidak lebih dari yang dibutuhkan'), karena secara tidak langsung penutur pasti mengatakan sesuatu yang berbeda dari maksud yang disampaikan. Dengan memberikan informasi yang kurang dari yang dibutuhkan atau yang dikatakan, maka terjadi pertimbangan dari $\mathrm{T}$ yang berhubungan dengan tekanan sosial terhadap hasil dari suatu interpretasi. Strategi pemahaman dapat ditemukan pada data berikut.

(4) $\mathrm{CH}$ : Alya dan Elis hati-hati ya?

CP: Elis pernah jatuh?

EL: Lihat Elis kaki ini!

Konteks : Ketika CH dan CP sedang bermain. CH mengingatkan kedua anak tersebut untuk berhati-hati.

Pada dasarnya tuturan $\mathrm{CH}$ pada data (4) hanya sebagai peringatan pada EL dan CP. Namun yang terjadi adalah peringatan dari $\mathrm{CH}$ menghasilkan topik pembahasan antara EL dan CP. Ketika pertanyaan CP "Elis pernah jatuh" disampaikan, CP sebenarnya membutuhkan jawaban pernah atau tidak pernah dari EL, tetapi yang terjadi adalah EL menanggapi dengan "Lihat Elis kaki ini”. Jawaban EL ini termasuk dalam strategi 
pemahaman melalui implikatur percakapan. Tanggapan EL "Lihat Elis kaki ini", memberikan informasi yang kurang dari yang dibutuhkan atau yang dikatakan, bahkan berbeda dengan pertanyaan $\mathrm{CP}$, maka terjadi pertimbangan dari mitra tutur yang berhubungan dengan tekanan sosial terhadap hasil dari suatu interpretasi. Dengan demikian, ketika EL menanggapi $\mathrm{CP}$, secara tidak langsung $\mathrm{CP}$ diajak untuk menginterpretasikan maksud dari tuturan EL yang berarti bahwa EL pernah jatuh.

\section{Pernyataan Lebih}

Pada strategi pernyataan lebih, pernyataan $\mathrm{N}$ dinyatakan lebih dari yang diperlukan. Dengan demikian $\mathrm{N}$ melanggar maksim kuantitas. Jika $\mathrm{N}$ mengatakan lebih dari yang diperlukan, terjadi pelanggaran maksim kuantitas dengan cara berimplikatur. Hal ini dilakukan pada skala yang lebih tinggi dari keadaan sebenarnya. Dengan demikian implikatur yang dihasilkan jauh melampaui apa yang dikatakan.

(5) $\mathrm{CH}(1)$ : Kemarin Elis ke ulang tahun Keila?

EL(1) : Elis ada.

$\mathrm{CH}(2)$ : Orang banyak atau sedikit Elis?

EL(2) : Juta-juta kakak.

$\mathrm{CH}(3)$ : Siapa yang antar Elis?

EL(3) : kakak Brayen.

Konteks: Percakapan terjadi ketika CH menanyakan tentang ulang Tahun sepupu Elis yang bernama Keila.

Data (24) melibatkan tuturan berimplikatur percakapan yang berlangsung pada setiap pergantian tuturan. Yang menjadi sorotan pada data (5) adalah tuturan EL(2) sebagai respons atas pertanyaan $\mathrm{CH}(2)$ "Orang banyak atau sedikit Elis?". Dengan melanggar maksim kuantitas, tuturan EL(2) "Juta-juta kakak" secara tidak langsung menggunakan stategi pernyataan lebih melalui implikatur percakapan. EL memberikan informasi yang berlebihan, padahal jika dihubungkan dengan kebutuhan $\mathrm{CH}$, jawaban 'banyak atau sedikit' sudah cukup untuk menjawab pertanyaan $\mathrm{CH}$. Implikatur yang dihasilkan EL(2) jauh melampaui apa yang dikatakan. Dengan demikian, strategi yang digunakan pada implikatur EL adalah strategi pernyataan lebih.

\section{Ironi}

Strategi ironi biasanya dilakukan, namun penggunaannya menyebabkan pelanggaran terhadap maksim kualitas. Tuturan $\mathrm{N}$ yang berstrategi ironi mengatakan kebalikan dari apa yang dia maksud. Pelanggaran terhadap maksim kualitas yang dimaksudkan terjadi jika terdapat petunjuk bahwa yang dimaksudkan adalah makna yang disampaikan secara tidak langsung. Petunjuk tersebut bersifat kontekstual, dan sering ditandai dengan partikel yang menyampaikan perasaan N. Biasanya penyampaian perasaan N yang ditunjukkan bertentangan dengan fakta-pernyataan.

Strategi ironi pada anak usia 3-6 tahun dapat diamati pada data berikut. 
(6) AL: Gio bisa bikin pesawat?

ST: Bisa... gampang... Enteng-enteng

Konteks: Percakapan terjadi ketika AL dan ST melihat gambar pesawat.

Pada data (6) jawaban ST dianggap melanggar maksim kualitas, dengan tujuan untuk mendapatkan efek dari AL. Maksim kualitas menetapkan bahwa setiap peserta pembicara harus mengatakan hal yang sebenarnya. Data (6) merupakan implikatur percakapan yang harus disesuaikan dengan fakta. Fakta yang terjadi ketika tuturan ST diujarkan berlawanan dengan hal yang sebenarnya terjadi, yaitu bahwa sebenarnya ST tidak bisa membut pesawat. Dengan mengatakan "Bisa... gampang... Enteng-enteng" implikatur percakapan disampaikan dengan strategi ironi, yang bertujuan untuk bercanda dengan AL. Melalui strategi ironi pada data (6) implikatur percakapan disampaikan anak usia 3-6 tahun untuk tujuan bercanda serta menyatakan secara tidak langsung bahwa ST tidak bisa membuat pesawat.

\section{Penggunaan Metafora}

Strategi metafora hampir sama dengan strategi ironi karena strategi metafora juga melanggar maksim kualitas. Strategi penggunaan metafora, tidak selalu direalisasikam dalam pengomparasian secara kasar. Strategi metafora dapat direalisasikan dengan cara berikut: (a) metaforanya menjadi bagian pertuturan berimplikatur percakapan, dan (b) yang ditonjolkan dalam pembandingan adalah suasana atau keadaan, bukan benda. Berikut disajikan data implikatur percakapan anak usia 3-6 tahun yang menggunakan strategi penggunaan metafora.

(7) HP (1): Dio sini saya pegang tasmu

DP (1): Kalau saya tidak mau?

HP(2) : Sini

DP(2) : Sudah. cerewet kayak mama mama

Konteks: Percakapan terjadi ketika DP mau pulang, tas DP mau dipegang Kakaknya.

Strategi metafora yang direalisasikan oleh DP pada data (7) sejalan dengan pendapat Brown dan Levinson (1987:222) yang menyatakan bahwa strategi penggunaan motafora lebih ditonjolkan dalam perbandingan. Tuturan DP "Sudah. cerewet kayak mama mama" menunjukkan peran implikatur dalam percakapan dengan menggunakan metafora. DP membandingkan sikap HP dengan sikap mama mama. Dalam hal ini unsur budaya ikut mengambil alih pertuturan. Kata mama-mama yang dimaksudkan DP adalah sikap keibuan. Dengan kata lain, mama mama sama dengan Ibu-ibu. Ibu-ibu biasanya identik dengan sikap peduli namun agak cerewet.

\section{Pertanyaan Retoris}

Strategi pertanyaan retoris direalisasikan oleh N. Pertanyaan retoris yang disampaikan $\mathrm{N}$ tidak mengikat $\mathrm{T}$ harus mematuhi ajakan $\mathrm{N}$. Jawaban $\mathrm{T}$ sebenarnya tidak perlu sekalipun $\mathrm{N}$ nampak membutuhkan jawaban dan jawaban atas pertanyaan $\mathrm{N}$ nampak 
penting untuk diberikan. Pada strategi ini skala untung- rugi dapat dilihat pada usaha $\mathrm{N}$ untuk meminimalkan kerugian $\mathrm{T}$. Dengan kata lain, $\mathrm{N}$ berusaha menyelamatkan muka dengan cara mengurangi tingkat ancaman terhadap mukanya. Dengan demikian diperlukan penggunaan pertanyaan retoris. Strategi pertanyaan retoris dapat dilihat pada data (30).

(8) $\mathrm{CH}$ : (merapikan barang-barang $\mathrm{CP}$ )

CP: Kakak Alya tinggal sendiri. Mama masih kerja. Kakak belum pulang kan?

Konteks: Percakapan terjadi ketika CH sedang bersama CP dan merapikan barangbarang $C P$

Pada data (8) pertanyaan retoris digunakanuntuk menyampaikan maksud. CP Nampak membutuhkan jawaban dan jawaban atas pertanyaan CP nampak penting untuk diberikan. Tuturan “Kakak Alya tinggal sendiri. Mama kasih kerja. Kakak belum pulang kan?” CP berusaha menyelamatkan muka dengan cara mengurangi tingkat ancaman terhadap mukanya. Berdasarkan skala untung rugi, CP mengurangi tingkat ancaman terhadap mukanya, sehingga cara yang digunakan $\mathrm{CP}$ dalam pertuturan adalah menggunakan strategi berupa pertanyaan retoris.

\section{KESIMPULAN}

Simpulan penelitian ini adalah bahwa implikatur percakapan anak usia 3-6 tahun muncul ketika anak berada dengan banyak orang, seperti berada dengan kumpulan temanteman yang sebaya dan orang dewasa di sekitarnya. Hal itu disebabkan ketika anak berada di luar rumah lebih banyak stimulus dari lingkungan dan situasi sehingga anak lebih berani dalam berbicara. Berdasarkan temuan, anak lebih cenderung menggunakan implikatur ketika bersama dengan orang lain atau orang sekitar anak. Hal itu sejalan dengan alasan bahwa komunikasi serta interaksi sosial sangat penting dalam kehidupan manusia.

Pada umumnya berinteraksi dengan sesama diperlukan karena manusia tercipta sebagai mahluk sosial. Oleh karena itu, keterampilan berbicara dimulai sejak kecil. Ketika anak belajar dari mendengar atau menyimak, anak juga dapat berbicara sesuai apa yang didengar. Dengan pengalaman yang cukup, anak akan fasih berbicara di depan umum tanpa canggung. Sama halnya dengan komunikasi memerlukan pengalaman dan interaksi dari orang sekitar, kemunculan implikatur percakapan anak juga ada ketika adanya interaksi dengan orang sekitar. Dengan kata lain, adanya hubungan sosial pembicara. Implikatur percakapan yang muncul pada tuturan anak usia 3-6 tahun dirumah juga ada, namun sangat minim. Keminiman penggunaan implikatur percakapan di rumah disebabkan faktor budaya dan tradisi yang mengikat anak. Tuturan berkembang ketika ada stimulus atau pemancingan dari seseorang untuk berbicara.

Implikatur percakapan bertujuan untuk menyampaikan keinginan lain dari apa yang dikatakan anak. Biasanya dalam percakapan, anak mempunyai agenda ketika menginginkan sesuatu yang disampaikan secara tidak langsung. Tindak tutur yang mengadung implikatur terdapat tujuan makna terselubung. Berdasarkan hasil temuan peneliti, strategi implikatur percakapan anak usia 3-6 tahun terdiri atas delapan strategi, 
yaitu strategi pemberian petunjuk, pemberian petunjuk asosiasi, praanggapan, pemahaman, melebih-lebihkan, ironi, penggunaan metafora, dan pertanyaan retoris. Temuan lapangan menunjukan bahwa strategi penggunaan tautologi dan strategi penggunaan kontradiksi tidak ditemukan dalam implikatur percapakapan anak usia $3-6$ tahun.

\section{DAFTAR PUSTAKA}

Brown, Gillian dan Yule, George. 1996. Discourse Analysis I(Analisis Wacana). Terjemahan Oleh I. Soetikno. 1996. Jakarta: Gramedia Pustaka Utama.

Brown, Penelope dan S.C.Levinson. 1987. Politeness Some Universals in Language Usage. Cambridge: Cambridge University Press.

Cummings, Louise. 2007. Pragmatik Sebuah Prespektif Multidisipliner. Yogyakarta: Pustaka Pelajar.

King, Laura. 2007. Psikologi Umum. Jakarta: Salemba Humanika.

Leech, Geoffrey diterjemahkan oleh Oka. 2011. Prinsip-prinsip Pragmatik. Jakarta: Universitas Indonesia Press.

Mulyana. 2005. Kajian Wacana Teoro, Metode dan Aplikasi prinsip-prinsip Analisis Wacana.Tiara Wacana:Yogyakarta.

Rahardi, Kunjana. 2005. Pragmatik Kesantunan Imperatif Bahasa Indonesia. Jakarta: Erlangga.

Yule, George. 2006. Pragmatik. Yogyakarta: Pustaka Pelajar. 